\title{
Social Influence and Occupational Knowledge as Predictors of Career Choice Intentions among Undergraduate Students in Tanzania
}

\author{
Jaquiline Amani \\ Faculty of Education \\ Mkwawa University College of Education, P.O Box 2512, Iringa Tanzania \\ Tel: 255- 758 481-869. Email:jakamaa@yahoo.co.uk \\ Accepted: June 15, 2013 Published: July 14, 2013 \\ Doi:10.5296/ijld.v3i3.3990 URL: http://dx.doi.org/10.5296/ijld.v3i3.3990
}

\begin{abstract}
The purpose of this study was to examine the extent to which occupational knowledge and social influence from significant others predict intentions of undergraduate students to join their careers upon completion of their studies in Tanzania. Based on its quantitative character, a cross-sectional survey design was opted. A convenient sample of 100 first and finalist undergraduate students (63 males, 37 females; age range 19 to 40 years) participated in this study. The structured questionnaire was used to assess the demographic characteristics, level of occupational knowledge, social influence, and career choice intentions. The study found that undergraduate students' intentions to join their careers were highly determined by their level of occupational knowledge and social influence from significant individuals such as parents, friends, and lecturers. It was further revealed that there was low but positive correlation between occupational knowledge and career choice intentions. Overall, the study found that majority of students intend to join their careers upon their graduation. Both practical and theoretical implications are discussed further in this study.
\end{abstract}

Key Words: Predictors, career choice intentions, social influence, occupational knowledge, university students, Tanzania.

\section{Introduction}

The question of how career choice is made has been frequently asked in the mind of researchers from time immemorial. Psychologists and other scholars have long been interested and engaged in research as to how people choose their careers and how they can be helped to do so effectively. In fact, a wide range of factors which determine individual's career choice have been researched worldwide. However, whether or not career choice motives predict intentions of university students to join what they have chosen to study upon their graduation is still question which needs an empirical investigation. This paper examined the extent to which social influence and knowledge about occupations predict university students' career choice intentions.

\section{Background}

Career development, for most people, is a lifelong process of engaging the world of work through choosing among available employment opportunities (Bandura et al., 2001). Each individual undertaking this complex process is influenced by many factors. Perhaps these factors may vary in context and culture. Globally, researchers have investigated factors influencing students' career choice in various fields of specialization. To mention a few, there is literature on the views of students on teaching career (See, 2004; Kyriacou \& Coulthard, 
2000). These studies revealed that the main reasons for student to choosing teaching career fall into three main areas, namely extrinsic factors, intrinsic factors and altruistic factors.

Extrinsic reasons cover aspect of jobs which are not inherent in work itself such as long holidays, level of pay and status. Intrinsic motives may be understood as entering the career for job-related factors like the nature of the job, for example, the activity of teaching children, chance for life-long learning and many opportunities that associated with the job. The third category is altruistic factors. These often go beyond tangible benefits that the career has to offer. Individuals who are motivated by altruistic reasons see teaching as a socially worthwhile and important job. They have a desire and passion to teach, a great love for children and desire to help society improve and make a difference to the lives of their students ( Kyriacou \& Coulthard, 2000).

In other careers, such as entrepreneurship, studies have shown that students' intentions to become entrepreneurs are partly influenced by attitude, self-efficacy, prior experiences and family exposure to business (Pihie, 2009; Haase \& Lautenschlager, 2011). However, social demographic characteristics such as age, gender were insignificant with the intentions to become entrepreneurs. For engineers, perceptions of a person -job fit and financial rewards were found to be the key motives for university students' career choice intentions (Suan, Mat \&Lin Im, 2012). The assumption that one could make based on these findings is that, motivation behind one's career choice intentions varies across professions and culture. However, none of the previous studies have examined the extent to which knowledge and social influence affect student' career choice aspirations in Tanzanian context. Thus, dearth of literature in Sub-Saharan African and Tanzania in particular gave the impetus of this study.

\section{The Need for the Study}

Career choice is important and perhaps a vey difficulty process in which one must undergo at one time in life. O'Brien (1996) asserts that everyone should have a honest occupation since work is one of our greatest blessings. However, most of people often make wrong career decisions due to lack of information, ignorance, peer pressure, wrong modeling or as a result of prestige attached to certain careers without adequate career guidance and career counselling (Salami, 1999; Ndambuki \& Mutie, 1999). Worth noting, studies have shown that the majority of students in Tanzania finish their secondary school education without adequate knowledge on career choice due to lack of proper career guidance and counselling (Puja, 2001; Mvungi, 2009). Consequently, they are directly or indirectly affected when enter to university education as the majority of them lack skills necessary to choose fields of specialization from variety of programmes offered in universities. The major question that upsurges is what predicts their intentions to become teachers, lawyers, engineers or entrepreneurs? Specifically, the study addressed the following research questions. First, what factors influence university students' choice of their degree programmes? Second, what is the level of relationship between students' occupational knowledge and career choice intentions? Third, is there a statistical significant variation in students' occupational knowledge across college affiliation, sex and year of study? Fourth, how do social influence from significant others such as parents, peers and friends influence students career choice intentions?

\section{Social Influence, Occupational Knowledge and Career Choice Intentions}

Several theories have been developed to explain occupational choice among individuals. These include: Holland's personality theory, Ajzen theory of planned behaviour, Roe theory of needs and Ginsberg theory. In their general view, career decision is a result of combination of both personal factors (those originating within individual) and situational factors i.e forces emerged from the social context. Personal factors (individual factors) include cognitive and mental processes which dictate career decision making such as attitude, self-concept, self-efficacy and 
knowledge (Sharf, 1992). On the other hand, social factors which are also viewed as external forces from the society may also affect ones career decisions. A good example for this is social influences from significant others. Therefore, individual's motives for career choice intentions are also determined by both personal and social oriented factors. A person is more likely to perform the behaviour if significant others support his or her intentions to do so (Ajzen, 2006). Social pressure may come from the family, teachers, friends, and the society in general.

Indeed, knowledge being a personal factor has a significant role for individual's career choice decisions. Every job seeker needs to be well informed about the requirements, work conditions, opportunities, salary and limitations associated with the intended career (Parsons as cited in Arnorld , 2005). Awareness of the occupational roles and knowledge of the current status of labour market has significant influence on individual's occupational aspirations. As observed by Kidd (2006) that when people are provided with adequate information at the right time, it can make a big difference in career planning. Thus, this study examined how occupational knowledge and social influence determines ones' decision whether or not to join the careers of his/her choice.

\section{Methods and Procedures}

\section{Design}

The study was mainly quantitative under a cross-sectional design using questionnaire as a main data collection tool. The choice of this design was attributed to two main reasons. First, it enabled the researcher to use data on frequency of a phenomenon to investigate the relationship between variable of interest among large group of people (Cohen, Manion \& Morrison, 2007). Furthermore, the design enabled the researcher to collect information on participants' demographic characteristics and occupational knowledge within a relatively short period of time.

\section{Study Site and Sample}

The study was conducted at the University of Dar es Salaam among undergraduate students from four degree programmes namely; Law, Education, Engineering, and Business. One hundred students aged between 19 and 40 years conveniently volunteered to take part in this survey. Amongst these, $63 \%$ were male while $37 \%$ were female. Majority of which, came from School of Law (28\%) followed by School of Education (27\%), then Business School $(25 \%)$ and lastly was College of Engineering which formed $20 \%$ of the participants. The target groups were first year students $(57 \%)$ and finalist students which were $43 \%$. The targeted degree programmes were selected because they lead into specific professions immediately upon graduation. Also, first years were expected to provide plausible factors that compelled them to select their respective degree programmes while final year students were vital in assessing whether or not they have any intentions to join the careers corresponding to their degree programmes upon graduation. The participants' demographic profile is summarized in the Table 1.

Table1:Social-demographic Profile of the Participants $(N=100)$

\begin{tabular}{lll}
\hline $\begin{array}{l}\text { Social-demographic } \\
\text { variable }\end{array}$ & Category & N \\
\hline Age & 20 years and below & 10 \\
& 21-30 years & 85 \\
Sex & 31-40years & 5 \\
& Male & 63 \\
Year of Study & Female & 37 \\
& 1 1 year & 57 \\
& Finalist & 43 \\
\hline
\end{tabular}


Name of college/school

$\begin{array}{ll}\text { SOL } & 28 \\ \text { SOED } & 27 \\ \text { UDBS } & 25 \\ \text { CoET } & 20 \\ \text { Employed } & 9 \\ \text { Unemployed } & 91\end{array}$

\section{Research Instruments}

A self-administered structured questionnaire with closed ended questions was used to collect data for this study. A covering sheet was attached to each questionnaire explaining the objectives of the study. There were a total of four sections in the questionnaire. Section (a) of the questionnaire assessed participant's social and demographic profile, section (b) measured participants' occupational knowledge, section (c) gathered the information regarding factors which influence students' choice of their degree programmes, social influence from significant others in influencing intentions to join their careers, and the last section (d) consisted of questions regarding dependent variable which assessed career choice intentions.

\section{Variables Measured}

In this study the following set of variables were used for statistical analyses.

Dependent Variable: Career Choice Intention (CCI) was treated as dependent variable for this study. Two items were used to measure career choice intention (CCI) of the participants e.g. "I expect to join my prospective career upon graduation and "I intend to join my prospective career upon graduation'. The strength of agreement was measured on a Likert-type of scale ranging from 1(strongly disagree) to 4 (strongly agree).

Independent Variables: Social pressure from significant others, occupational knowledge and social-demographic information were termed as independent variables. In a Likert scale form, 8 items assessed students' knowledge about careers i.e. occupational knowledge. The responses were indicated on a four Likert scale from 4 (strongly agree) to 1(strongly disagree). Participants were asked to tick the extent to which they either agree or disagree with the items. The occupational knowledge was measured by the summed score of the eight items which ascertained the participant's knowledge about what their prospective careers offer, salary, the challenges and prospects of their prospective career. The minimum score one was expected to obtain was 8 while the maximum score was 32 with higher scores implying high occupational knowledge. To ensure the internal validity of the items, an internal reliability test using Cronbachs' Alpha was conducted with $\mathrm{r}=.75$ which was a relative high internal consistency implying that the scale was reliable. With respect to social influence from significant others, participants were asked to rate the most important individuals whom might influence their intentions to join their prospective career upon their graduation. Frequencies on the responses were cumulated to obtain the total percentages.

\section{Data Management and Analysis}

Data analysis involved both descriptive and inferential statistics. The computer package for social sciences (SPSS) version 17 was used for all analyses. Bivariate associations were performed with Pearson's (r) correlation coefficient to determine the relationship between occupational knowledge and career choice intentions (CCIs). One way Analysis of Variance (ANOVA) was used to examine the effect of college affiliation and age on scores of occupational knowledge. An independent sample t-test was also performed to compare the scores of knowledge between different groups i.e male and female, and students'year of study. 


\section{Results}

\section{Motives Behind University Students' Choice of their Degree Programmes}

The prospective careers referred to in this study were those occupations which the students were expected to join upon graduation in relation to the degree programmes they pursued. The researcher was eager to explore what factors made students choose their degree programmes and if they intend to join or not upon their graduation. Among the motives mentioned to have influenced students choice of their degree programmes were self-interest (31\%) followed by easiest way to get employed (17\%) and last was influence from parents (14\%). This means that most of students were self-motivated to study their degree programmes as such, they had intrinsic motivation to study.

Table 2: Factors Influencing University Students' Choice of their Degree Programmes

\begin{tabular}{|c|c|c|c|c|}
\hline Variable & Motives & $\mathbf{N}(\%)$ & Mean & SD \\
\hline 1.Choice of the degree & 1. Self interest & 31 & 7.38 & .84 \\
\hline \multirow[t]{8}{*}{ programme } & 2. Parental influence & 14 & 6.64 & 1.39 \\
\hline & 3.Good performance & 6 & 7.16 & .98 \\
\hline & 4. Ease employment & 17 & 6.64 & 1.35 \\
\hline & 5. Respect of the profession & 5 & 6.20 & 2.04 \\
\hline & 6. Dreams to own business & 4 & 6.75 & .95 \\
\hline & 7. Prior work experience & 3 & 6.66 & 1.15 \\
\hline & 8. Self- employment & 8 & 7.12 & .99 \\
\hline & 9. Status of the career & 8 & 7.5 & 1.06 \\
\hline
\end{tabular}

Another factor pointed out by students especially from the field of education was the loan availability. Given the fact that there is high demand for students' loans, along with a limited budget the government priority is given to students who have been admitted to pursue national priority programmes including education. This situation has also acted as career choice motivation for most of students in the field of education. Most of students (27\%) who chose teaching as their career were more influenced by availability of loan from the government. Nevertheless, the economic background of the majority of students is poor therefore; most of them depend on the government loan to finance their education. Again, this affects the career choices of many undergraduate students such that; the majority will be just hunting to the programmes in which they are assured of the government sponsorship.

Students' Level Occupational Knowledge

Table 3: Summarizes the Results Regarding the Students' Level of Occupational Knowledge.

\begin{tabular}{cccccc}
\hline S/N & Knowledge Items & Very Much & Much & Little & Very little \\
& & $\%$ & $\%$ & $\%$
\end{tabular}

$1 \quad$ I am aware of the existence of my career in the world 57 of work

2 I know about what my career offers in the world of 56 work

3 I am well informed about the requirements and 45 limitations of my prospective career

$4 \quad$ I am aware of the existence of sources of career 41 information regarding my prospective career

5 Accurate information about occupational 40 opportunities helps to make a sound career choice

$6 \quad$ How much do you know about different careers?

57
56
45
41
40
31
25

\section{7 \\ 37 \\ 42 \\ 48 \\ 60}

46

41
0

0

2

0

2 
occupation do ?

you are currently pursuing?

The findings indicated that majority of students (53\%) scored above the median value of 27 implying that were well informed about their careers in terms of their existence, working hours, the challenges entailed. For example, from the table, majority of participants $57 \%$ were very much aware about the existence of their careers in the world of work. Also, they knew about what their career offers $(48 \%)$ and the associated job practices which are done by the people already employed in their fields of interest $(60 \%)$.

The study also assessed whether or not there was a significant difference in the level of occupational knowledge across sex, year of study and collage/school affiliation. The independent sample $t$-test was conducted to compare scores of occupational knowledge between male and female students, first year and finalist students. Results showed that there was no statistically significant difference in scores for males $(M=26.41, S D=3.00)$ and female $(M=25.94, S D=4.18) ; t(100)=1.05, p=.29$. Similarly, there was no statistically significant difference in scores of occupational knowledge with respect to first year students $(M=26.04$, $S D=3.90)$ and finalist $(M=26.25, S D=3.20) ; t(100)=-.28, p=.77)$. However, when One- way between groups ANOVA was performed to examine the variations in career knowledge with respect to college affiliation a statistically significant difference emerged at $p=.05$ in scores of occupational knowledge across four colleges namely: Business School $(M=25.52$, $S D=3.45)$, School of Education $(M=24.74, \mathrm{SD}=3.38)$, School of Law $(M=27.14, S D=3.69)$, College of Engineering $(M=27.35, S D=2.62) ; F(3,98)=3.54, p=.01$. This implies that students who affiliated in the colleges of engineering and law were more familiar with their prospective careers than those in other colleges/schools.

The study further explored the relationships between occupational knowledge and career choice intentions. Findings revealed low but positive correlation between occupational knowledge and career choice intention $r=.16, n=100, p=.102$ meaning that higher levels of occupational knowledge were associated with higher scores on career choice intentions. As such, the more knowledgeable one was about different careers the more he/she intended to join it upon graduation.

\section{Social Influence from Significant others and Career Choice Intentions}

Nevertheless, the influence of social pressure from significant others on career choice intentions was also examined. Students were asked to rate important individuals who were more influential to their decisions to become teachers, lawyers, entrepreneurs and engineers. The most significant individual pointed out were father (30\%) followed by lecturer $(20 \%)$, then by friends (16\%). Table 4 shows the summary of the results.

Table 4: Influence from significant others on Career Choice Intention

\begin{tabular}{llll}
\hline Category & $\mathbf{N}$ & Mean & SD \\
\hline Father & 30 & 7.30 & .92 \\
Mother & 10 & 6.90 & 1.37 \\
Peers & 6 & 6.0 & 1.26 \\
Friends & 17 & 6.8 & 1.86 \\
Relatives & 14 & 7.0 & .73 \\
My lecturer & 20 & 7.0 & 1.02 \\
Counsellor & 3 & 7.3 & 1.15 \\
Total & 100 & & \\
\hline
\end{tabular}


Moreover, with regard to whether or not students intend to join their prospective careers upon graduation results show that majority $(90 \%)$ of the participants strongly agreed that they intend to join their prospective career upon graduation. Only $10 \%$ of the participants had no intentions of joining the professions they have chosen to study.

\section{Discussions}

Findings showed that students' motives behind the choice of their degree programmes ranged from personal, economic, social and psychological factors. In particular, self-interest was the main factor which influenced students' choice of the degree programme. However, the availability of loan from the government and job security added value for pre-service student teachers' decisions to pursue career in education. This was due to the fact that it was ease for them to secure loan from the government and get employment soon upon their graduation. These results suggest that sometimes people's decisions to choose a career or not are partly determined by what a particular career offers (i.e the attached values) in terms of economic benefits in one hand, and financial support on the other side. Perhaps, the possible attributes could be what prevails in the labour market and one's economic strengths which together may lead to change of career choice motives among students.

However, a change in motivational level behinds one's career choice is likely to affect individual's commitment at work and future career development since most individuals will be driven mostly by extrinsic motives which are likely to be threats to a stable working force of nation. Arguably, teaching unlike other careers needs intrinsic motivation such that this shift in motivational factors can have implications both at individual in particular and national level in general. Unless university students are choosing their professions for sound reasons universities will continue to produce graduates who dislike their training programmes (Conners, 2000) and who hastily decide to leave their profession out of disillusionment (Jones, Glatthorn, \& Bullock, 2006).

Furthermore, the results showed that majority of university students are informed about their prospective careers. This means that students' career knowledge was sufficient in terms of what their prospective careers offer, limitations, challenges and even the salary of their prospective career. It was further revealed that there was a positive relationship between occupational knowledge and intentions of students to join their careers upon graduation. Indeed, with exception of college or school affiliation, gender and year of study had no any significant effect on student's level of occupational knowledge. The implication was that students' occupational knowledge varies across colleges and school of affiliations.

Interestingly, the study revealed that the decisions whether to join a career or not was partly determined by the social influence from significant others whose thoughts are valuable to the students. Significant others include parents, peers, friends, lecturers, and relatives. These findings could be attributed to the fact that family as the main socializing agent plays a significant role in providing information to the children about different occupations. This study draws support from findings of Agarwala (2008), and Lugumila (2010) who found that parents especially father and other male relatives play the most significant role in influencing their children's career choice intentions. Likewise, lecturers were also said to have influence on student's career choice intentions as they act as a role model to their students. For example, a study by Akinjide and Sehinde (2011) established that teacher' characteristics such as mode of communication was one of the key factors influencing student teachers' intentions to become teachers upon graduation. However, it was noted that the influence from cousellors (3\%) was very low compared to other individuals with the implication that career counseling services are not highly offered to university students in the context of Tanzania. 


\section{Conclusions and Implications}

Generally, from these findings it can be concluded that the overwhelming majority of the students intend to join the careers they were pursuing upon completion of their studies. Also, there is a closer relationship between what a student knows about a particular career and his or her intentions to join or not. This implies that students need to be more informed about their careers for them to understand the outlook of the labour market in relation to their chosen field of study. It is recommended that the university management should establish and strengthen of career counseling services so as to provide occupational information to students basing on their needs. Other studies should take part to assess the effects of extrinsic career choice motives on professional commitment. The results of this study should however be taken with great caution due to the small sample size of 100 participants and sampling procedures involved. The larger sample could have brought a varied responses and inferences. On the other hand, students who participated in this study were conveniently selected thus limits the generalizability of the findings to wider population and contexts.

\section{References}

Agarwala, T. (2008). Factors influencing career choice of management students in India. Career Development International , 13, (4), 362-376.

Ajzen, I. (2006). Constructing a theory of planned behavior questionnaire. Accessed from http://people.umass.edu/aizen/pdf/tpb.measurement.pdf.

Akinjide, G. A., \& Sehinde, A. (2011). Teacher characteristics and students' career choice of teaching as career in Osun State. Edo Journal of Counselling, 4 (1),

116-129.

Arnold, J. (2005). Work psychology: Understanding human behaviours in workplace. London: Prentice Hall.

Bandura, A., Barbaranelli,C., Caprara, G.V., \& Pastorelli,C (2001. Self-efficacy beliefs as shapers of children's aspirations and career trajectories, Child Development,72,187201.

Cohen, L,. Manion, L., Morrison, K. (2007). Research methods in education. $6^{\text {th }}$ edition. London : Routledge.

Connors, T. G. (2000). Reasons pre-service teachers choose secondary social studies at three Midwest institutions. Journal of Social Studies Research, 24(2), 39-48.

Haase, H., \& Lautenschlager. A. (2011). Career Choice Motivations of University Students. International Journal of Business Administration. 2 (1), 2-13.

Jones, B.D., Paretti, M.C., Hein, S.F., \& Knott, T.W (2010). An analysis of motivation constructs with first -year engineering students; Relationships among expectancies, values, achievement, and career plans. Journal of Engineering Education, 319-336.

Kidd, L.M. (2006). Understanding career counselling: Theory, research and practice. London: Sage Publications.

Kyriacou, C., \& Coulthard, M. (2000). Undergraduates' views of teaching as career choice. Journal of Education for Teaching, 26 (2).

Lugumila,U.(2010). The influence of gender stereotyping on career choice among secondary school students. Unpublished M.A9ASP) Dissertation. University of Dar es Salaam.

Mvungi, G. (2009). School- based factors influencing students' choices of teaching science as career. The case of government secondary schools in Ilala District.

Unpublished M.A Dissertation. University of Dar es Salaam.

Ndamuki, P., \& Mutie, E. K. (1999). Guidance and counselling for schools and colleges. Kenya: Oxford University Press. 
O'Brien, T. (1996). A case study of six students in workbound. Unpublished Dissertation, University of Winsconsin-Milwaukee.

Pihie, Z. A. (2009). Entrepreneurship as a career choice: An analysis of entrepreneurial self- efficacy and intention of university students, European Journal of Social Science, 9 (2), 338-349.

Puja, G. K. (2001). Moving against the grain: The expectations of Tanzanian female undergraduate students of university of Dar es-Salaam. Unpublished $\mathrm{PhD}$ Thesis. University of Toronto.

Salami SO 1999. Relationship between work values and vocational interests among high school students in Ibadan. Nigerian African Journal of Educational Research, 5(2): 6574.

See, B. H. (2004). Determinants of teaching as a career. Paper Presented at the British Educational Research Association Annual Conference, University of Manchester: New York.

Suan, C., Mat, N., \& Im, T. (2012). What drives the career choice among engineers? A case in Malaysian manufacturing plant. International Journal of Research Studies in Management, 1(2), 15-24. Retrieved in April, 2012 from http://consortiacademia.org/index.php/ijrsm/article/viewFile/60/59

Sharf. R. S. (1992).Applying career development theory to counseling. USA: Brooks/Cole. 